\section{Assessing Chilling Tolerance in Roses using Chlorophyll Fluorescence}

\author{
Nadia Hakam ${ }^{1}$,Shahrokh Khanizadeh ${ }^{2}$, Jennifer R. DeEll ${ }^{3}$, and \\ Claude Richer ${ }^{4}$ \\ Agriculture and Agri-Food Canada, Horticultural Research and Development \\ Centre, 430 Boulevard Gouin, St-Jean-sur-Richelieu, QC, J3B 3E6, Canada
}

Additional index words. spring frost, hardiness, Rosaceae, low temperature injury, winter damage, nondestructive method, Rosa kordesii, $R$. hybrida, $R$. rugosa, $R$. arkansana

\begin{abstract}
Chlorophyll fluorescence (CF) was evaluated as a technique to assess chilling injury of rose (Rosa sp.) leaves exposed to low temperatures. In the more susceptible genotypes, variable fluorescence $(\mathrm{Fv})$ decreased dramatically as the temperature was lowered. In the less susceptible genotypes, $\mathrm{Fv}$ was more stable and decreased more slowly as temperature fell. Our results suggest that measurement of $\mathrm{CF}$ may provide a rapid method to prescreen genotypes for chilling susceptibility, as required in plant breeding.
\end{abstract}

Chilling injury can be defined as damage occurring at temperatures near freezing, and can affect plants in the field in early spring and late fall. Plants sensitive to chilling must be grown in heated greenhouses with high energy costs. In order to reduce heating costs, plant breeding programs have been designed to select genotypes more resistant to chilling. The usual selection procedure is growth analysis (Den Nijs and Smeets, 1987). Unfortunately, such selection procedures are time-consuming and the development of new genotypes usually requires many years. Commonly used techniques to measure the chilling tolerance of plants are visual expression of necrosis (VEN), vital staining (VSP), differential thermal analysis (DTA), and freeze-induced electrolyte loss (FIEL). Each of these methods has disadvantages, and the comparison of results among method is subjective, the results may differ between observers, the appearance of injury generally requires an extended period of time, and the large sample size necessary is often impractical to obtain (Burr et al., 1990). However, VEN requires no specialized equipment. The VSP method is difficult to use, timeconsuming, and requires special equipment. The DTA technique is inaccurate when plants are in the process of hardening and dehardening,

Received for publication 19 May 1998. Accepted for publication $14 \mathrm{Apr}$. 1999. Contribution number 335/98.05.02R of the Horticultural Research and Development Centre, Agriculture and Agri-Food funding provided by Horizons sciences program of publishing this paper was defrayed in part by the payment of page charges. Under postal regulations, this paper therefore must be hereby marked adver-

${ }^{1}$ Postdoctoral Fellow, Physiologist.

${ }^{2}$ Research Scientist and Adjunct Professor, Breeder and Physiologist; to whom reprint requests should be addressed (e-mail: khanizadehs@em.agr.ca).

${ }^{3}$ Research Scientist, Postharvest Physiologist.

${ }^{4}$ Research Scientist, Ornamental Nursery Management. different methods is often difficult. The VEN Canada. The authors gratefully acknowledge the Agriculture and Agri-Food Canada. The cost of tisement solely to indicate this fact. and the results often vary considerably, making calibration difficult (Burr et al., 1990). Although FIEL is a very sensitive method, it generally is time-consuming and requires researchers to define an arbitrary point at which irreversible tissue damage is assumed to occur (DeHayes and Williams, 1989).

Genotype selection based on chilling tolerance could be improved by the availability of a screening test that is rapid, nondestructive, and applicable to young plants. Most chlorophyll fluorescence (CF) studies on temperature responses of plants have focused on the determination of low and high temperature limits of growth (Lichtenthaler, 1988; Weis, 1981). Recently, CF has been used to study cellular processes other than photosynthesis, the possible responses of plants to various stresses, including chilling/freezing tolerance in particular (Brennan and Jefferies, 1990; Sundblad et al., 1990; Walker et al., 1990).

Several studies have suggested that in vivo $\mathrm{CF}$ can be used as a rapid screening technique for stress tolerance in crop plants, including chilling (Hetherington et al., 1983a, 1983b; Neuner and Larcher, 1990; Smillie and Nott, 1979; Sthapit et al., 1995), freezing (Strand and Öquist, 1988), and heat, radiation, and drought stress (Havaux and Lannoye, 1985; Lichtenthaler, 1988). Several studies have indicated that reductions in $\mathrm{CF}$ occur in plants at temperatures near their chilling threshold. Smillie and Nott (1979) reported that the decrease in $\mathrm{CF}$ of leaves during rapid chilling at $0{ }^{\circ} \mathrm{C}$ can be used as an index of the chilling sensitivity of plant species. Wilson and Greaves (1990) reported that CF offers considerable potential in accelerating the quantitative assessment of chilling injury, as it is rapid, sensitive, nondestructive, and relatively inexpensive, and is able to detect injury before visible symptoms occur. It also can be used for estimating the chilling tolerance of plants.

The objective of this study was to test whether in vivo measurements of $\mathrm{CF}$ could provide a rapid and simple method for assessing chilling tolerance in roses and to determine if there was any association between $\mathrm{CF}$ and chilling injury. In addition, in vivo $\mathrm{CF}$ of detached and attached leaves was measured to determine if detachment affected response.

\section{Materials and Methods}

Plant material. Thirteen genotypes with several degrees of chilling sensitivity were used; all were ranked using the VEN method (Table 1). Rosa kordesii 'Captain Samuel Holland', 'George Vancouver', 'John Cabot', and 'William Baffin'; R. hybrida 'JP Connell'; $R$. rugosa 'David Thompson'; $R$. rugosa 'F95' and 'Ottawa'; and $R$. arkansana 'Prairie Joy' (obtained from Agriculture and AgriFood Canada, L'Assomption, Qué.) were evaluated by Reseau d'Essai des Plantes Ligneuses Ornementales du Québec (REPLOQ)(Conseil des Producteurs Végetale du Québec, 1990) using the VEN method. Rosa hybrida 'Autumn Sunblaze', 'Sunny Sunblaze', and 'Betty Prior'; and R. arkansana 'Prairie Fire' (purchased from Bailey Nurser-
Table 1. Fv measurements and F values for detached and attached leaves of Rosa genotypes, the decrease of $\mathrm{Fv}\left(\beta_{1}\right)$ over time when the leaves were subjected to $0^{\circ} \mathrm{C}$, and the chilling sensitivity of the genotypes in the literature as classified by visual expression of necrosis (VEN) method. Expt. 1.

\begin{tabular}{|c|c|c|c|c|c|c|}
\hline \multirow[b]{2}{*}{ Species } & \multirow[b]{2}{*}{ Cultivar } & \multicolumn{2}{|c|}{ Fv } & \multirow[b]{2}{*}{ F-value ${ }^{z}$} & \multirow{2}{*}{$\begin{array}{l}\text { Slope }\left(\beta_{1}\right) \\
\text { Detached }\end{array}$} & \multirow{2}{*}{$\begin{array}{c}\text { Chilling } \\
\text { sensitivity } \\
\text { (VEN method) }\end{array}$} \\
\hline & & Detached & Attached & & & \\
\hline \multirow[t]{3}{*}{ Rosa rugosa } & Ottawa & 146 & 159 & $1.00^{\mathrm{Ns}}$ & $-1.51^{* *}$ & Very resistant $\mathrm{t}^{\mathrm{y}}$ \\
\hline & F-95 & 189 & 215 & $1.27^{\mathrm{Ns}}$ & $-1.64^{* *}$ & Very resistant ${ }^{\mathrm{y}}$ \\
\hline & David Thompson & 121 & 114 & $1.03^{\mathrm{NS}}$ & $-1.72^{* *}$ & Very resistant ${ }^{\mathrm{y}}$ \\
\hline \multirow[t]{4}{*}{ Rosa kordesii } & William Baffin & 231 & 242 & $1.66^{\mathrm{NS}}$ & $-1.57^{* *}$ & Very resistant ${ }^{\mathrm{y}}$ \\
\hline & George Vancouver & 187 & 196 & $1.33^{\mathrm{NS}}$ & $-1.91^{* *}$ & Resistant $^{\mathrm{x}}$ \\
\hline & John Cabot & 129 & 134 & $1.29^{\mathrm{NS}}$ & $-2.06^{* *}$ & Resistant $^{y}$ \\
\hline & Capt.Samuel Holland & 212 & 218 & $1.15^{\mathrm{Ns}}$ & $-2.16^{* *}$ & Resistant $^{\mathrm{y}}$ \\
\hline \multirow[t]{2}{*}{ Rosa arkansana } & Prairie Joy & 157 & 158 & $1.11^{\mathrm{Ns}}$ & $-1.79^{* *}$ & Resistant $^{\mathrm{x}}$ \\
\hline & Prairie Fire & 202 & 189 & $1.66^{\mathrm{Ns}}$ & $-2.28^{* *}$ & Sensitive $^{w}$ \\
\hline \multirow[t]{4}{*}{ Rosa hybrida } & JP Connell & 198 & 218 & $1.27^{\mathrm{Ns}}$ & $-1.74^{* *}$ & Resistant $^{\mathrm{y}}$ \\
\hline & Sunny Sunblaze & 213 & 231 & $1.55^{\mathrm{Ns}}$ & $-2.13^{* *}$ & Very sensitive $^{w}$ \\
\hline & Autumn Sunblaze & 162 & 170 & $1.21^{\mathrm{Ns}}$ & $-2.48^{* *}$ & Very sensitive $^{w}$ \\
\hline & Betty Prior & 183 & 195 & $1.02^{\mathrm{Ns}}$ & $-2.31^{* *}$ & Very sensitive $^{w}$ \\
\hline
\end{tabular}

${ }^{\mathrm{z}}$ All values nonsignificant at $P \leq 0.05$.

y Conseil des Producteurs Végetale du Québec (1990).

${ }^{x}$ Richer et al. (1997).

wInformation obtained from Bailey Nurseries (St Paul, Minn.) based on VEN classification.

${ }^{* *}$ Significant at $P \leq 0.01$ by $\mathrm{F}$ test. 
ies, St. Paul, Minn.) were evaluated by Bailey Nurseries using the VEN method. Six plants of each genotype were grown and tested for $\mathrm{CF}$ from November to January. They were maintained under a 16 -h light period, at $20^{\circ}$ to $22^{\circ} \mathrm{C}$ day $/ 16^{\circ}$ to $18^{\circ} \mathrm{C}$ night. Plants were watered when necessary and fertilized once a week with $20 \mathrm{~N}-20 \mathrm{P}-20 \mathrm{~K}$ at a rate of $80 \mathrm{mg} \cdot \mathrm{L}^{-1}$.

Chlorophyll fluorescence measurements. Plants or leaf samples from each replicate were kept in the dark at $25^{\circ} \mathrm{C}$ for $2 \mathrm{~h}$ to avoid pre-irradiation by visible light, which can alter the fluorescence measurements (Smillie and Hetherington, 1990). A single, green, 40-W safelight was used to provide a low level of illumination during the fluorescence analysis, allowing the operator to see well enough to handle the plants and to operate the instrument. Measurements were made with an OS500 Modulated Fluorometer (Opti-Sciences Ltd., Tyngsboro, Mass.), using the Fv/Fm test (method 1 on the fluorometer). Modulation intensity was set at 100 and the detector gain at 40 , with the saturation light (35-W halogen lamp) intensity set at 190 for $0.8 \mathrm{~s}$. The Fv (variable fluorescence) was used for data analysis and was calculated as

$$
\mathrm{Fv}=\mathrm{Fm}-\mathrm{Fo}
$$

where Fo and Fm are the minimal (the constant background fluorescence level) and the maximal fluorescence, respectively, of a darkadapted sample. Measurements were made on the central region of the leaf, avoiding the midvein in attached and detached, well-hydrated leaves. During chilling, repetitive Fv measurements were recorded every $2 \mathrm{~s}$ for $80 \mathrm{~s}$ on the same portion of the leaf by placing the prechilled sensor of the portable fluorometer on the exposed upper surface of the leaf.

Expt. 1. Since both fluorescence and chilling tolerance can vary with the age of the leaf, the choice of plant tissue to sample becomes important when making comparisons between different genotypes. In our study, comparisons were made using fully expanded nonsenescing leaves. The six apical fully expanded leaves, as well as six randomly selected young leaves, were detached from each plant and treated as described under "Chlorophyll fluorescence measurements" above. Harvested leaves were placed immediately into plastic petri dishes containing moist filter paper. The petri dishes were placed in a darkened chamber kept at $70 \%$ relative humidity at $25^{\circ} \mathrm{C}$ for $2 \mathrm{~h}$; then the Fv was recorded.

Expt. 2. Similar genotypes were used in this experiment to measure the effect of temperature on Fv. Only detached leaves were used, since in Expt. 1 no significant difference was observed between detached and attached leaves (Table 1). After initial measurements at $25^{\circ} \mathrm{C}$, the detached leaf samples were exposed to $10^{\circ} \mathrm{C}$ for $24 \mathrm{~h}$, to $5^{\circ} \mathrm{C}$ for $24 \mathrm{~h}$, and finally to $0{ }^{\circ} \mathrm{C}$ for $24 \mathrm{~h}$. The $\mathrm{Fv}$ was then measured following each exposure.

Statistical analysis of data. A completely randomized design with six replicates (plants) was used for each experiment. The relationship $\left(\beta_{1}\right)$ between Fv value over time (Expt. 1) and the decrease in temperature (Expt. 2) was
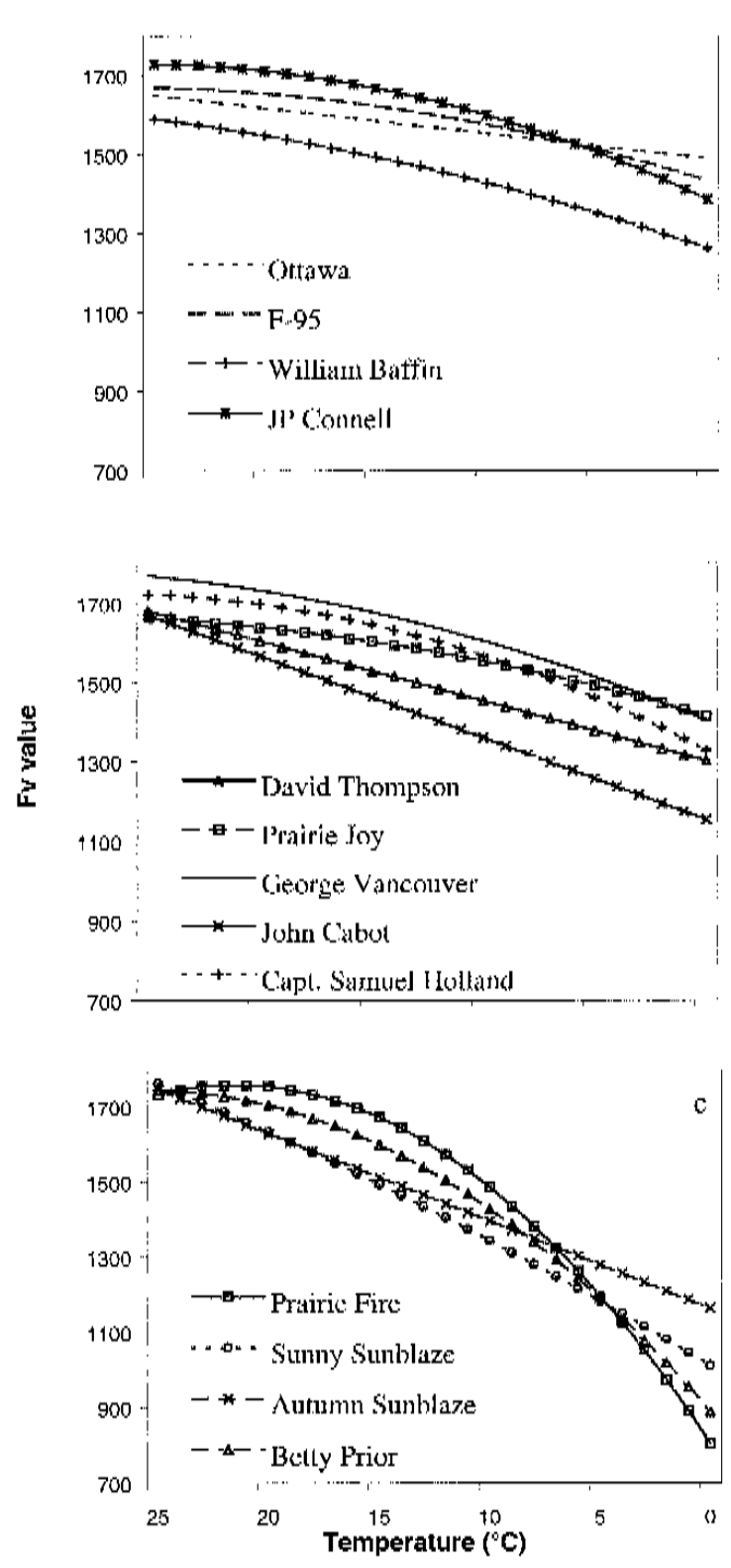

Fig. 1. Changes of Fv with temperature for 13 genotypes of roses classified as (A) very resistant, (B) resistant, and (C) sensitive. Expt. 2.

calculated using the GLM procedure of SAS (SAS Institute, 1989).

\section{Results}

Expt. 1. Changes of Fv during chilling were the same for attached and detached leaves, provided that the detached leaves were kept well hydrated (Table 1), as change in water status prior to or during chilling can alter the severity of chilling response (Wilson, 1976).

The Fv decreased with time in all genotypes when the leaves were held at $0{ }^{\circ} \mathrm{C}$; however, the slopes were not identical (Table $1)$. The rapidity of the decrease in $\mathrm{Fv}\left(\beta_{1}\right)$, or negative slope, increased with the chilling tolerance of the genotype as classified in the literature (Table 1). The more resistant genotypes had lower slopes than did the very sensitive genotypes.

Expt. 2. The changes in Fv with temperature for the intermediate genotypes (Fig. 1B) were between those for the least (Fig. 1C) and most chilling-tolerant genotypes (Fig. 1A). Values for the least tolerant genotype $(R$. hybrida 'Betty Prior') decreased markedly at lower temperatures, whereas little change occurred in the leaves of the very resistant genotype ( $R$. rugosa 'Ottawa'). For example, after $3 \mathrm{~d}$ at $0{ }^{\circ} \mathrm{C}, \mathrm{Fv}$ of the chilling tolerant $R$. rugosa 'Ottawa' decreased by only $10 \%$, whereas that of the least tolerant genotype fell $>50 \%$ (Table 2).

\section{Discussion}

Results with the CF method were similar to those with VEN (Conseil des Producteurs Végetale du Québec, 1990; Richer et al., 1997). The small differences observed in Table 1 between classification based on VEN vs. CF could have been due to VEN being based on an observer's subjectivity.

The decrease in Fv of all genotypes con- 
firms the findings of Hetherington et al. (1983a, 1983b), who introduced screening methods based on changes in Fv to assess the relative tolerance of crop plants to chilling and heat stresses. The decrease in Fv in roses with decreasing temperatures followed a pattern similar to that of other crops, e.g., peanut (Arachis hypogaea L.), maize (Zea mays L.), and rice (Oryza sativa L.), that are susceptible to chilling injury (Smillie and Hetherington, 1990). Therefore, a relationship between the decrease of $\mathrm{Fv}$ at $0{ }^{\circ} \mathrm{C}$ and chilling sensitivity exists and this may be used for selection in breeding programs. In this study, the rates of decrease in Fv agreed, for the most part, with the expected relative chilling sensitivity of the rose genotypes tested.

Our results indicate that $\mathrm{CF}$ can be used to assess differences in chilling tolerance between genotypes. The strong relationship between chilling tolerance determined via visual and fluorescence techniques supports the inference that rapid reduction in fluorescence indicates actual tissue injury. Measurement of fluorescence after controlled chilling appears to be an excellent method for determining chilling tolerance in roses, and this method is more rapid and less tedious than the techniques currently used.

The CF method is relatively rapid, reliable, nondestructive, quantitative, and diagnostic. In comparison with other methods described in the introduction, CF probably has the greatest potential for quality assessment in nurseries, as well as in breeding programs. Measurement of CF is a useful method for the early recognition and quantitative measurement of cellular disturbance caused by low temperature injury. It could possibly be used to detect genotypes that are not susceptible to low temperature injury during the winter, but no such relationship has been reported to date. Our results indicate that the $\mathrm{CF}$ method can be used on detached leaves in vitro without destroying the plants.

\section{Literature Cited}

Brennan, R.M. and R.A. Jefferies. 1990. The use of chlorophyll fluorescence in assessment of low temperature hardiness in blackcurrant (Ribes nigrum L.). Ann. Appl. Biol. 117:667-672.

Burr, K.E., R.W. Tinus, S.J. Wallner, and R.M. King. 1990. Comparison of three chilling hardiness tests for conifer seedlings. Tree Physiol. 6:351-369.

Conseil des Producteurs Végetale du Québec. 1990.

Table 2. Effect of temperature on Fv in leaves of 13 genotypes of rose as a percentage of initial value (six replicates of each). Expt. 2.

\begin{tabular}{|c|c|c|c|c|c|c|c|}
\hline \multirow[b]{2}{*}{ Species } & \multirow[b]{2}{*}{ Cultivar } & \multicolumn{4}{|c|}{ Temp $\left({ }^{\circ} \mathrm{C}\right)$} & \multirow[b]{2}{*}{ Effect $^{2}$} & \multirow{2}{*}{$\begin{array}{c}\text { Slope } \\
\left(\beta_{1}\right)\end{array}$} \\
\hline & & 25 & 10 & 5 & 0 & & \\
\hline \multirow{3}{*}{ Rosa rugosa } & Ottawa & 100.0 & 93.7 & 91.8 & 90.5 & $\mathrm{~L}^{*}$ & $6.41^{*}$ \\
\hline & F-95 & 100.0 & 95.9 & 89.0 & 86.9 & $\mathrm{Q}^{*}$ & $17.42^{\prime}$ \\
\hline & David Thompson & 100.0 & 91.1 & 85.3 & 79.7 & $\mathrm{~L}^{*}$ & $15.11^{*}$ \\
\hline \multirow[t]{4}{*}{ Rosa kordesii } & William Baffin & 100.0 & 93.5 & 86.2 & 80.8 & $\mathrm{Q}^{*}$ & $18.87^{*}$ \\
\hline & George Vancouver & 100.0 & 89.3 & 85.7 & 79.1 & $\mathrm{Q}^{*}$ & $23.61^{*}$ \\
\hline & John Cabot & 100.0 & 87.0 & 82.3 & 77.3 & $\mathrm{~L}^{*}$ & $20.59^{*}$ \\
\hline & Capt. Samuel Holland & 100.0 & 85.8 & 72.4 & 70.3 & $\mathrm{Q}^{*}$ & $29.25^{*}$ \\
\hline \multirow[t]{2}{*}{ Rosa arkansana } & Prairie Joy & 100.0 & 91.0 & 85.0 & 77.1 & $\mathrm{Q}^{*}$ & $16.41^{*}$ \\
\hline & Prairie Fire & 100.0 & 80.0 & 72.4 & 67.1 & $\mathrm{Q}^{*}$ & $88.86^{*}$ \\
\hline \multirow[t]{4}{*}{ Rosa hybrida } & JP Connell & 100.0 & 93.0 & 90.8 & 85.0 & $\mathrm{Q}^{*}$ & $26.46^{*}$ \\
\hline & Sunny Sunblaze & 100.0 & 77.0 & 66.6 & 57.9 & $\mathrm{Q}^{*}$ & $35.54 *$ \\
\hline & Autumn Sunblaze & 100.0 & 85.4 & 64.3 & 53.1 & $\mathrm{~L}^{*}$ & $23.32^{*}$ \\
\hline & Betty Prior & 100.0 & 87.9 & 67.3 & 47.4 & $\mathrm{Q}^{*}$ & $67.18^{*}$ \\
\hline
\end{tabular}

${ }^{2} \mathrm{~L}=$ linear; $\mathrm{Q}=$ quadratic.

"Significant at $P \leq 0.05$ by $\mathrm{F}$ test.

Méthode d'essais du Réseau d'Essais des Plantes Ligneuses Ornementales du Québec (REPLOQ). Min. Agr. Pêch. Alim., Québec, 6ème rév.

DeHayes, D.H. and M.W. Williams, Jr. 1989. Critical temperature: A quantitative method of assessing chilling tolerance. Dept. Agr.-For. Serv., Gen. Tech. Rpt. NE-134, Broomall, Pa.

Den Nijs, A.P.M. and L. Smeets. 1987. Analysis of differences in growth of cucumber genotypes under low light conditions in relation to night temperatures. Euphytica 36:19-32.

Havaux, M. and R. Lannoye. 1985. In vivo chlorophyll fluorescence and delayed light emission as rapid screening techniques for stress tolerance in crop plants. Z. Pflanzen. 95:1-13.

Hetherington, S.E., R.M. Smilie, A.K. Hardacre, and H.A. Eagles. 1983a. Using chlorophyll fluorescence in vivo to measure the chilling tolerances of different populations of maize. Austral. J. Plant Physiol. 10:247-256.

Hetherington, S.E., R.M. Smilie, P. Malagamba, and Z. Huaman. 1983b. Heat tolerance and chilling tolerance of cultivated potatoes measured by the chlorophyll-fluorescence method. Planta 159:119-124.

Lichtenthaler, H.K. 1988. In vivo chlorophyll fluorescence as a tool for stress detection in plants, p. 129-142. In: H.K. Lichtenthaler (ed.). Applications of chlorophyll fluorescence. Kluwer Academic, Dordrecht, The Netherlands.

Neuner, G. and W. Larcher. 1990. Determination of differences in chilling susceptibility of two soybean varieties by means of in vivo chlorophyll fluorescence measurements. J. Agr. and Crop Sci. 164:73-80.

Richer, C., J.A. Rioux, and J. Côté. 1997. Rusticité et croissance de plantes ligneuses ornementales au Québec. Tome II. Conseil des Prod. Vég. du Québec.

SAS Institute. 1989. SAS user's guide, ver. 6.0. SAS Inst., Cary, N.C.
Smillie, R.M. and S.E. Hetherington. 1990. Screening for stress tolerance by chlorophyll fluorescence, p. 229-261. In: Y. Hashimoto, H. Nonami, P.J. Kramer, and B.R. Strain (eds.). Measurement techniques in plant science. Academic, San Diego.

Smillie, R.M. and R. Nott. 1979. Assay of chilling injury in wild and domestic tomatoes based on photosystem activity of the chilled leaves. Plant Physiol. 63:796-801.

Sthapit, B.R., J.R. Witcombe, and J.M. Wilson. 1995. Methods of selection for chilling tolerance in Nepalese rice by chlorophyll fluorescence analysis. Crop Sci. 35:90-94.

Strand, M. and G. Öquist. 1988. Effects of frost hardening, dehardening and freezing stress on in vivo chlorophyll fluorescence of seedlings of Scots pine (Pinus sylvestris L.). Plant, Cell Environ. 11:231-238

Sundblad, L.G., M. Sjöström., F. Malmberg, and G. Öquist. 1990. Prediction of frost hardiness in seedlings of Scots pine (Pinus sylvestris L.) using multivariate analysis of chlorophyll fluorescence and luminescence kinetics. Can. J. For. Res. 20:592-597.

Walker, M.A., D.M. Smith, K.P. Pauls, and B.D. McKersie. 1990. A chlorophyll fluorescence screening test to evaluate chilling tolerance in tomato. HortScience 25:334-339.

Weis, E. 1981. Reversible heat-inactivation of the Calvin cycle: A possible mechanism of the temperature regulation of photosynthesis. Planta 151:33-39.

Wilson, J.M. 1976. The mechanism of chill and drought hardening of Phaseolus vulgaris leaves. New Phytol. 76:257-270.

Wilson, J.M. and J.A. Greaves. 1990. Assessment of chilling sensitivity by chlorophyll fluorescence analysis, p. 130-139. In: C.Y. Wang (ed.). Chilling injury of horticultural crops. CRC Press, London. 